\title{
Social Projects in the Activities of Commercial Enterprises and Organizations: Implementation Features
}

\author{
Svetlana Osadchaya ${ }^{1 *}$ \\ ${ }^{1}$ Federal State Autonomous Educational Institution of Higher Education «Belgorod State National Research \\ University»), Belgorod, Russia \\ *Email: osad_star@inbox.ru
}

\begin{abstract}
The paper points to the actualisation of the issues of social responsibility of enterprises and organizations operating in the context of the development of a socially-oriented economy and the use of social design in this regard as a tool for the implementation of social goals and programs in the context of the project management concept used. The work aims to obtain information about the possibility of implementing social projects by economic entities based on the experience of their implementation in the practice of managing economic entities. The study's working hypothesis assumes the importance and possibility of implementing social projects in the activities of organizations engaged in entrepreneurial activity both from the point of view of social and from the standpoint of economic efficiency. The assessment of the implemented social projects in the activities of a distribution company of regional significance allowed us to verify the reliability of the hypothesis put forward to identify problematic aspects of social design at the organizational level.
\end{abstract}

Keywords: Social responsibility, Project management, Social design, Social project.

\section{INTRODUCTION}

In current conditions of development of socioeconomic relations, socialisation of the economy, issues of social responsibility of enterprises and organizations engaged in entrepreneurial activity, their implementation of social goals and objectives, participation in solving social problems are significant. Being direct participants in market relations, economic entities, in addition to their obvious commercial functions, are able to form and optimise the social space by implementing social goals and objectives concerning staff, consumers, partners and society as a whole. One of the most effective relevant tools for implementing social activities is currently a social project implemented within the current project management concept framework.

\section{RESEARCH HYPOTHESIS}

Research hypothesis based on the fact that project management and social projects implemented within the framework of this concept is an effective tool for the permanent effective development of the organization from the strategic perspective.

Social design is a purposeful activity to construct the desired state of an economic entity through purposeful transformations in the social sphere (personnel, their development, communication, teamwork, team building, improving working conditions, ensuring social security, developing corporate culture, caring for employees, etc.) is a factor in ensuring social stability, a catalyst for innovative transformations in all areas of the organization, and also acts as an indicator of the effectiveness of the socio-economic development strategy implemented in the organization. 
At the same time, in contrast to the prevailing opinion about the perception of social projects as, exclusively, items of expenditure in the organization, we point out the importance of implementing social projects not only from the point of view of social efficiency but also from their economic significance in the long-term development of the organization

\section{RESEARCH METHODS}

The results presented in the article are based on comparative and system analysis methods, economic research methods, and a systematic and structuralfunctional approach to the study of conceptual problems.

\section{RESEARCH RESULTS}

Modern realities of economic development with the characteristic actualisation and strengthening of social orientation dictate the need to develop a mechanism for the functioning of economic entities that combine commercial profitability and economic efficiency with elements of social orientation of activity, which ensures permanent development of organizations in the long term, contributes to strengthening competitive positions, increasing loyalty from consumers and partners [1, pp. 15-25].

The essential effective management tool at the level of organizations is currently project activity, in particular, social design, which allows for the desired transformations in the activities and infrastructure of an economic entity focused on permanent development in a strategic perspective [2, pp. 199205].

As a set of instructions, actions and recommendations that are necessarily reflected in a set of project documents [3, pp. 277-283], a social project is used as a guide to action to solve relevant social problems regarding employees, consumers, partners and society as a whole [4, pp. 43-52].

Thus, the system of management of social projects is a complex of measures for the collection, analysis of information necessary for the development and implementation of the project [5, pp. 59-63] and the formalization and use of effective methods and practices, contributing to the solution or to solve the social problems [6, pp. 123-132] (the labor market regulation, the creation of new jobs [7, pp. 123-132], training of employees, etc.) (Figure 1).

However, the implementation of social projects is mainly perceived as an activity incompatible with entrepreneurial activity since it requires additional costs for their implementation, which, in turn, contradicts the principle of profit maximization.

We, in turn, believe that in the strategic

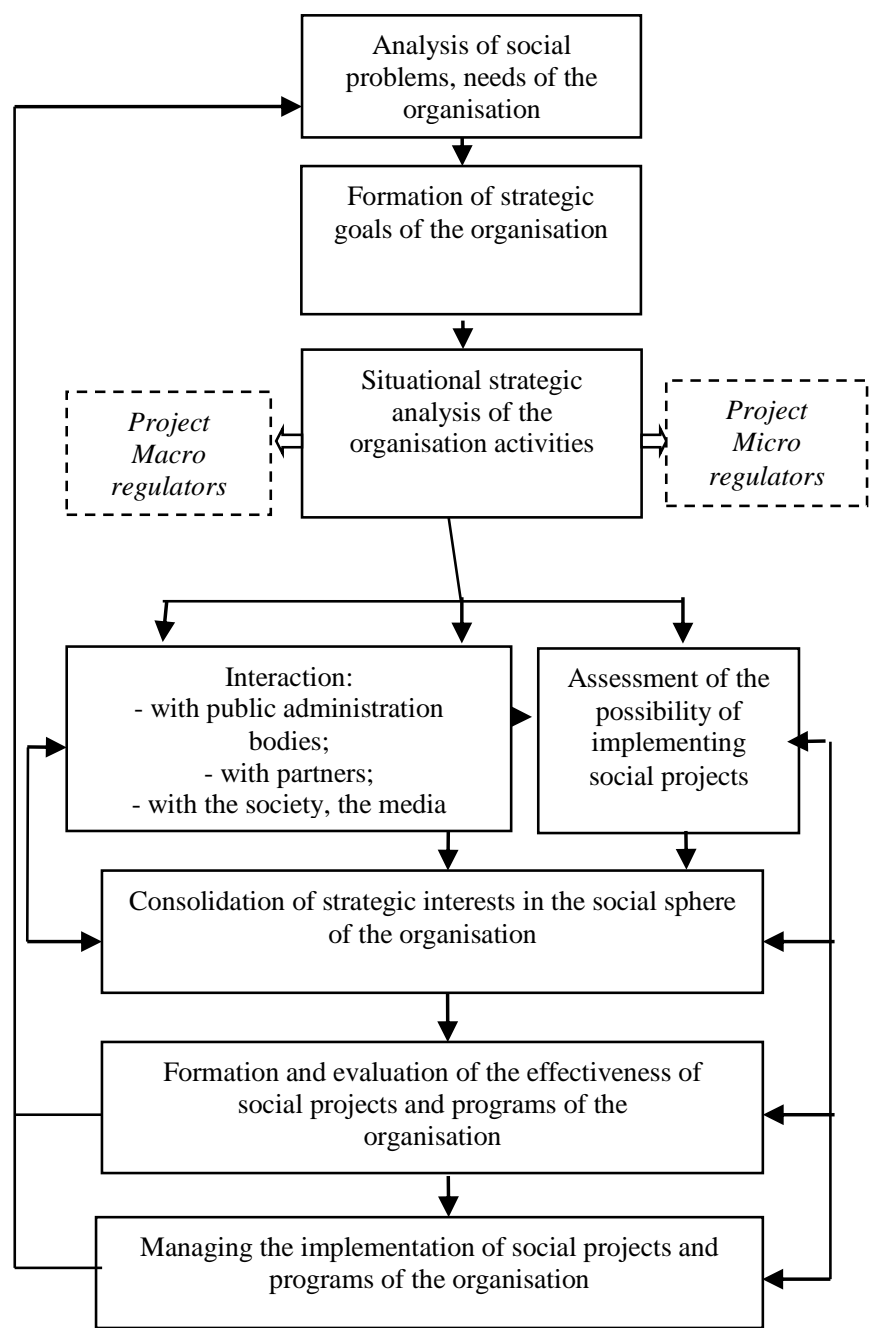

perspective, social projects are very effective not only from the standpoint of the social component but also are of interest from the point of view of obtaining a positive economic effect.

Figure 1 The algorithm for the development and implementation of social projects of the organization.

A large distribution company "Askon" LLC was chosen as the object of the study, the main activity of which is the wholesale of food products. The company has been successfully operating since 1994 and currently has a branch network covering 16 regions. The central office of the company is in Voronezh.

The organization has more than 50,000 serviced trade enterprises, warehouses, a fleet of vehicles to implement logistics activities, including more than 400 trucks, about 3,000 employees.

The company is actively developing a corporate project management system. The number of complex projects and project participants is increasing, indicating the need for the informatization of the project management system. As of September 2021, the project activity of "Askon" LLC is characterized by the following parameters: 
- Implemented projects belong to the category of complex projects (the implementation period is more than one year, high-cost, more than five divisions of the enterprise participate);

- Calendar and network schedules of work on open projects have a complex structure of work division; in most projects, the schedule has more than 100 works;

- Three projects in the initiation stage belong to the category of complex projects, one of which belongs to the category of social, the other two are heterogeneous and have a local social orientation (as an element);

- More than 70 people are directly involved in the project activities of the Company.

The company has established and successfully operates a project committee, thanks to which coordination and strategic management of the LLC's project activities are ensured, priority, strategically essential directions of the organization's development are identified, an effective system of selecting projects based on their projected effectiveness is built, resources are systematically distributed, and the actions of individual project teams are coordinated. The personnel management system is made so that employees of the organization are motivated to generate ideas and initiate new projects and their implementation. At the same time, special attention is paid to the effectiveness of project activities, both social and, of course, economic.

From the standpoint of the social effectiveness of project activities in the organization, it is possible to distinguish: the development of personnel involved in project activities and the improvement of the qualification level, as well as the acquisition of new professional competencies, the development and improvement of teamwork skills, the improvement of communication skills, orientation towards obtaining a positive synergistic effect.

It is sometimes difficult to calculate the economic effect of project activities, primarily due to the lack of data on cost reduction or profit generation associated with the use of project methods in the short term [8, pp. 1554-1556]. The reason is that to conduct an efficiency analysis, a certain amount of information is needed, which is missing, for example, at the stage of project implementation, or its quantity is insufficient to obtain reliable results. It should also be noted that the corporate project management system covers the social projects of "Ascon" LLC, which are noncommercial and, sometimes, do not initially imply a mandatory profit.

As a tool for analysing the effectiveness of the corporate project management system, we will use the method of net present value (net discounted income) [9, pp. 404-410].
Based on the available preliminary budget for projects, the implementation of which is expected in the period from 2021 to 2024 and the budget of closed and currently implemented projects, it is possible to trace the budget of projects in the context of six years. For further calculations, it is necessary to measure the impact of the corporate project management system on cost savings during project implementation. To do this, we will use the average percentage of cost savings, which is justified above.

$$
C s=\sum_{i=1}^{n} P b i * F c s
$$

where, Cs - cost savings,

$\mathrm{Pbi}$ - project budget in the i-th year,

Fcs is the cost-saving factor.

The budget of the development projects of "Ascon" LLC and the calculation of savings are shown in Figure 2 (Figure 2).

The costs of implementing a corporate project management system and its support consist of the following components: salaries of project management service employees, consulting, staff training, implementation of an information project management system as a means of automation and informatisation of project activities, an effective tool for planning, support, monitoring and control over the implementation of projects, in particular, social.

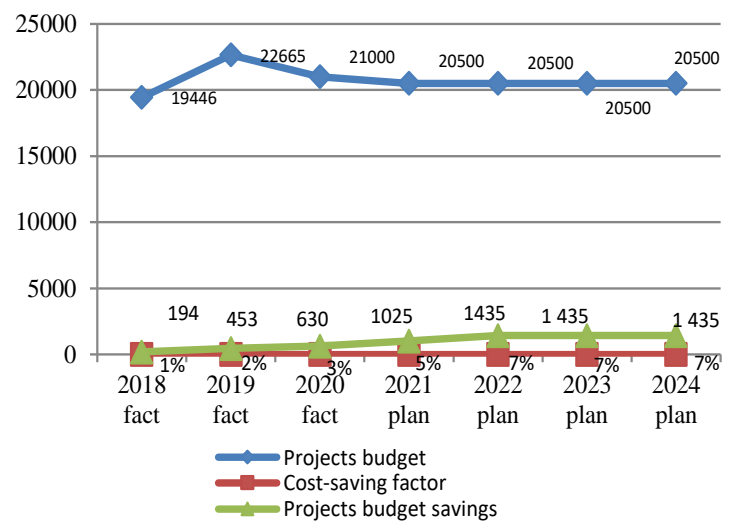

Figure 2 The budget of development projects of "Askon" LLC by year, thousand rubles.

The company has experience in implementing information technology projects (projects "Optimisation and automation of the warehouse storage system", "Creation and implementation of an automated document management system"). Project participants independently use the MS Project local version and have different skills to work with this software. 
As part of the implementation of social projects, possible alternative options for choosing the most relevant platform were considered. Primavera, Microsoft Project, OpenPlan, SPIDER and other products were evaluated. The choice was made on an intermediate solution - implementing the system on the Microsoft+ EPM platform, independent development of additional components that extend the basic functionality. So, the company is developing a separate web application that will allow, based on disparate data stored in the databases of the information system, to form unified reporting forms illustrating design deviations in the form of colour indicators, tables, graphs, diagrams, etc. This reporting centre allows, if necessary, to detail information "failing" to the level of each specific task, document, risk, issue, etc.

Data on the costs of implementing a corporate project management system and its maintenance are shown in Figure 3 (Figure 3).

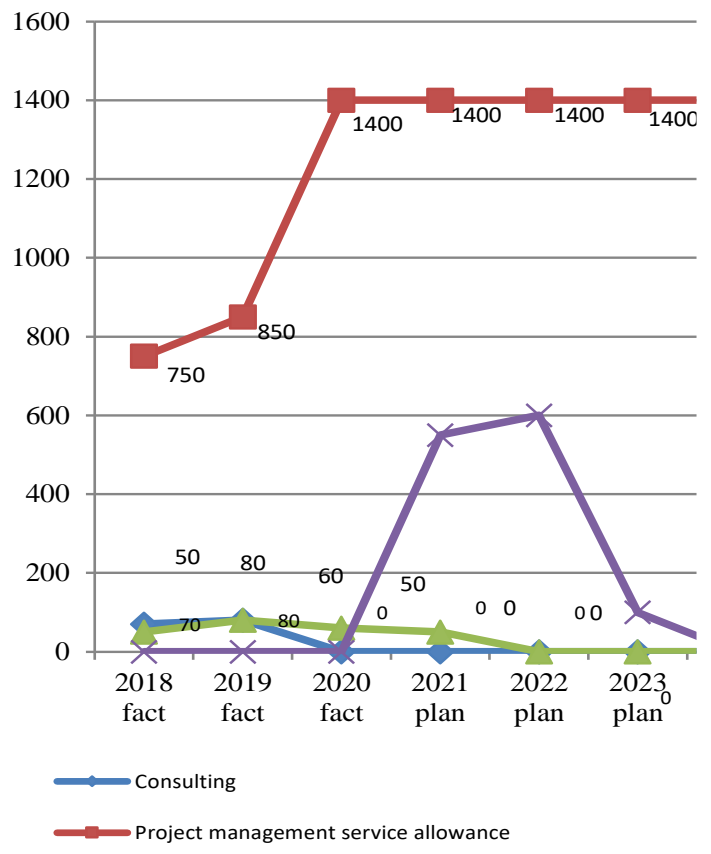

Figure 3 Costs for implementing and maintaining the corporate social project management system in "Askon" LLC, thousand rubles.

The project activity at "Ascon" LLC is based on a matrix type, i.e. the employee combines his main work with participation in the implementation of the project. Within management accounting, we will calculate the labour costs of an employee participating in project activities. According to calculations carried out by the project management service, the employee's participation in the project takes an average of $5 \%$ of his working time per day. Let's call this indicator the employee participation rate in the project; in our case, it will be equal to 0.05 .

$$
E t=R p * T
$$

where Et is the time spent by the employee to participate in the project in days,

$\mathrm{Rp}$ - employee participation rate in the project,

$\mathrm{T}$ is the duration of the project in days.

Using the cost savings coefficient and the average daily wage rate of an employee of "Ascon" LLC, we calculate the savings on the remuneration of one participant in the project activity according to the formula:

$$
S r=E t * S R d * F c s
$$

where $\mathrm{Sr}$ is the savings on the remuneration of one participant in the project activity,

Et - the time spent by the employee to participate in the project in days,

SRd - the average daily salary rate of an employee,

Fcs is the cost-saving factor.

The calculation data on cost savings and labour costs are shown in Figure 4.
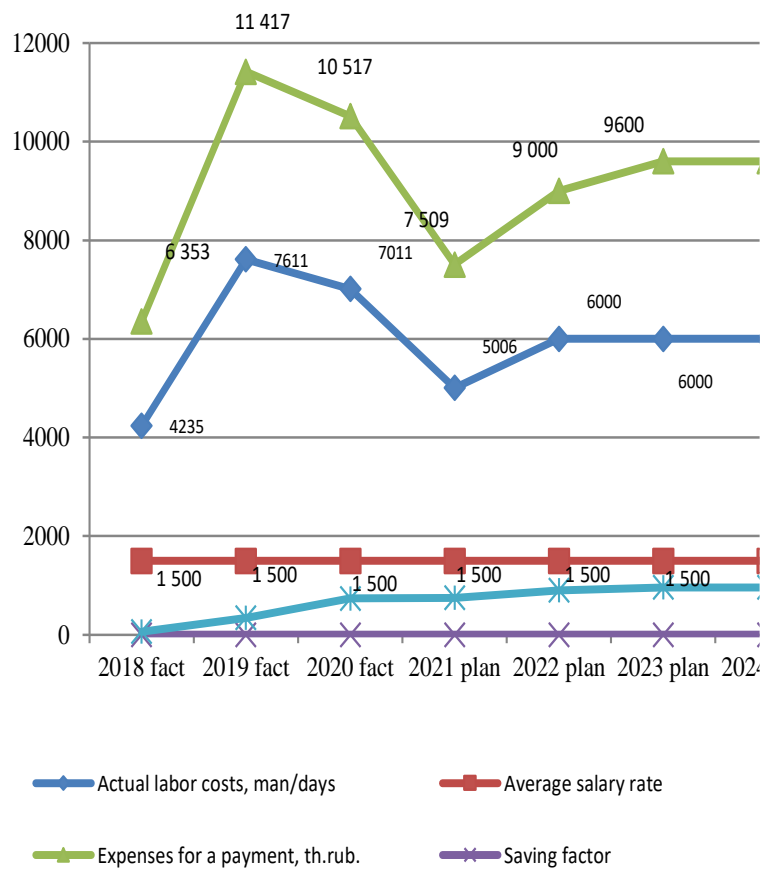

Figure 4 Savings on costs and labour costs of "Ascon" LLC from the implementation of social projects.

It follows from the analysis that the implementation of a corporate project management system is characterised by high costs associated with the involvement of consultants, staff training, acquisition and commissioning of an information system. 
Calculate cash flows (Figure 5).

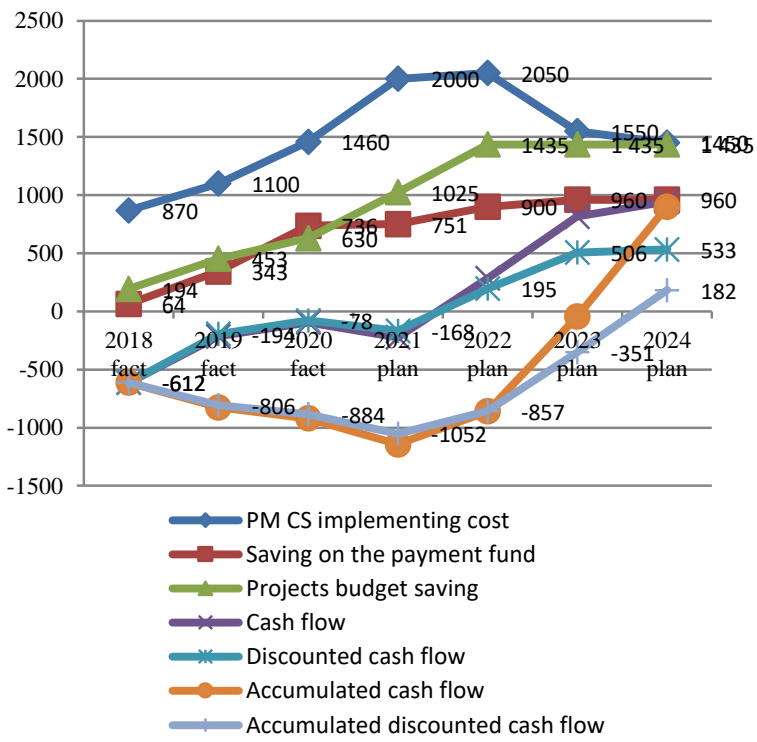

Figure 5 Analysis of cash flows of project activities of "Askon" LLC, thousand rubles.

In addition, in the initial period after the start of the implementation and operation of the corporate system, the effect of cost savings generating positive cash flow is set at a minimum level. However, with the expansion of the number of project management tools, such as corporate project management standards, the growth of the project management service, the increase in the number of trained personnel and the implementation of the project management information system, the returns expressed by positive cash flows are also growing. The discounted payback period falls in the middle of 2023 when most of the internal social development projects of "Ascon" LLC are implemented within the project management framework.

Considering the assumption introduced in the organization about $7 \%$ cost savings from the use of project methods of work, with a worldwide practice of $10-15 \%$ [10, pp. 138-142], and the scale of the projects being implemented, we can talk about the effectiveness of the implementation of the corporate social project management system in "Ascon" LLC.

At the same time, an important fact is that social design, aimed at stabilising social relations and solving social problems, is an effective management tool not only at the level of enterprises and organizations [11, 62-68]. The implementation of social activities by business structures is a recognised trend in developing a socially-oriented economy since it will contribute to the development of the territory, the optimisation of social relations [12, 1132-1150], the implementation of state and territorial social development programs.

\section{CONCLUSIONS}

The assessment of the possibility and features of the implementation of social projects by commercial enterprises and organizations as an effective modern tool for improving the competitiveness of economic entities in the strategic perspective allowed us to confirm the hypothesis we put forward earlier. Thus, the evaluation of social projects implemented by a large distribution company within the framework of the project management concept used in the organization made it possible to determine not only the apparent components of social efficiency but also using the net discounted income method; results were obtained indicating the effectiveness of the implementation of the corporate social project management system in the organization.

In particular, social design in the organization and information system based on the Microsoft+ EPM platform is recommended for implementation to optimise and improve project management efficiency. Currently, the company is working on the development of a separate web application for social projects.

\section{REFERENCES}

[1] P. Kotler, Social Marketing: Changing Behaviours for Good / P. Kotler, N.R. Lee -5 th ed. - SAGE Publishings, 2016, 548 p.

[2] S.M. Osadchaya, Features of social design in the conditions of economic transformations, its place and role in the organization's management system [Osobennosti social'nogo proektirovaniya $\mathrm{v}$ usloviyah ekonomicheskih preobrazovanij, ego mesto i rol' v sisteme menedzhmenta organizacii], Bulletin of the Belgorod University of Cooperation, Economics and Law [Vestnik belgorodskogo universiteta kooperacii, ekonomiki i prava] 4 (2015) 199-205.

[3] L.S. Yezhova, A.V. Voronin, P.P. Rumyantseva, Features of social project management [Osobennosti upravleniya social'nym proektom], Actual issues of modern Economy [Aktual'nye voprosy sovremennoj ekonomiki] 8 (2020) 277283.

[4] A.O. Ovcharov, T.N. Ovcharova, Social Design as a Management process: Conceptual Context [Social'noe proektirovanie kak upravlencheskij process: konceptual'nyj kontekst], Sociodynamics [Sociodinamika] 1 (2020) 43-52.

[5] V.V. Seregina, L.N. Shapovalova, M.N. Seredina, Social design and construction as a sociophilosophical theory and social practice [Social'noe proektirovanie i konstruirovanie kak 
social'no-filosofskaya teoriya i obshchestvennaya praktika], Scientific and Methodological electronic journal "Concept" [Nauchnometodicheskij elektronnyj zhurnal «Koncept»] 40 (2016) 59-63.

[6] V.P. Fedko, Formation of marketing thinking as a paradigm of value creation in the course of the modern evolution of marketing concepts [Formirovanie marketingovogo myshleniya kak paradigmy sozdaniya cennostej $\mathrm{v}$ hode sovremennoj evolyucii koncepcij marketinga], Financial Research [Finansovye issledovaniya] 1 (2017) 123-132.

[7] D.O. Nijhuis, Incomes Policies, Welfare State Development and the Notion of the Social Wage // SocioEconomic Review, Oxford Journals 13(4) (2015) 771-790.

[8] V. Tkhorikov, Technology of municipal public health service assessment, European researcher 11 (2011) 1554-1556.

[9] E.A. Stryabkova, A.S. Glotova, J.V. Lyshchikova, I.V. Chistnikova, I.N. Titova, Modeling and forecasting of socio-economic development of the region, The Journal of Social Sciences Research 5 (2018) 404-410.

[10]B.A. Thorikov, Basic elements of project management in the public sector of the economy, Topical issues of economics and management [Bazovye elementy proektnogo upravleniya $\mathrm{v}$ obshchestvennom sektore ekonomiki, Aktual'nye voprosy ekonomiki i upravleniya], Buki-Vedi, 2017, pp. 138-142.

[11] O.A. Lomovtseva, O.A. Gerasimenko, Investments in Russian infrastructure: problems and solutions [Investicii v rossijskuyu infrastrukturu: problemy i resheniya] // VIEPP Bulletin [Vestnik VIEPP] 2 (2019) 62-68.

[12]M. Reisch, J.S. Jani, The New Politics of Social Work Practice: Understanding Context to Promote Change // The British Journal of Social Work 42(6) (2012) 1132-1150. 